DOI 10.31558/2519-2949.2018.3.17

УДК 323.2:84'42:001.82

Котов Е. В., Донецький національний університет імені Василя Стуса

\title{
ТЕОРЕТИЧНІ ЗАСАДИ ЗАСТОСУВАННЯ ДИСКУРС-АНАЛІЗУ ДЛЯ ДОСЛІДЖЕННЯ ПОЛІТИЧНОГО СУБ'ЄКТА
}

У статті проаналізовано теоретичну еволюиію наукового кониепту "суб'єкт", крізь призму різноманітних історико-філософських епох та наукових доктрин. Подано парадигмальну періодизацію розвитку зазначеного конщепту із теоретичними доповненнями тих наукових икіл, щьо счинили вплив на постсучасне розуміння суб 'єкта в рамках сочіально-політичного знання. Автором наведено основні теоретичні наробки щодо розуміння конщепту суб'єктності в рамках наступних теоретико-практичних доктрин: соціологічний підхід (представлений аналізом пращь Ч. Кулі); ранній та класичний марксизм (між якими проводиться диференціація щзодо розглядаємого питання за вектором гуманізм / сочіологізм (антигуманізм)), включаючи франиузьку неомарксистську школу, представлену роботами Л. Альтюссера; психоаналіз, який дозволив визначити важливість несвідомого як конституюючого вектору суб 'єктності; аналітична психологія із акиентом на архетипічному складі несвідомого; постмодернізм (представлений прачями Ж. Дерріда, Ж. Ф. Ліотара, Ю. Крістевої, Р. Барта), що ставить питання текстуальної деконструкиії онтології та будь-якої форми логочентризму; окрім того, проаналізовано конщепт "влади" в роботах М. Фуко в його зв'язку із трансформачією розуміння суб'єктності та дискурсу. На основі зазначеного, автор намагається довести, щзо сучасний тип розуміння суб 'єкта бере свій відлік з філософії епохи Просвітництва, розуміючи при цьому вичерпність пояснювального потенціалу існуючої моделі, автор вказує на історико-культурну обумовленість будь-якої епістеми, припускаючи, що на даному етапі наукового знання необхідно говорити про аналіз суб'єкта в рамках дискурсивної методології, що дозволить розкрити нові шляхи в розумінні постучасних політичних прочесів.

Ключові слова: суб'єкт, дискурс, постмодернізм, постструктуралізм, "смерть суб'єкта".

У сучасних політичних дослідженнях вкрай гостро стоїть проблема ідентичності. Вона привертає увагу у рівній мірі як політологів, так й соціологів, культурологів та філософів. Це пов'язано із явищем, яке в політичній науці прийнято визначати як «криза ідентичності», яке полягає в трансформації людської суб'єктності. Свій вираз це віднаходить у зростаючій невизначеності у світлі як зміни умов т. з. матеріального світу, так й в перегляді наукової спадщини, що окреслює традиційний суб'єкт соціально-політичного знання. Дане питання привертає увагу вагомої частки закордонних вчених, серед яких можна виділити С. Холла [18], Дж. Торфлінга, Д. Ховарда та багато інших, проте в рамках вітчизняної науки це питання висвітлено, як нам здається, в недостатній мірі.

Отже, метою даної публікації є визначення теоретичної еволюції наукового концепту суб'єкт та доведення доцільності застосування постструктуралістської дискурсивної методології для його аналізу.

Згідно С. Холлу, трансформація постсучасного суспільства наприкінці ХХ ст. обумовлена, в першу чергу, фрагментацією культурних ландшафтів класу, полу, сексуальності та винесенням питань, що мають відношення до сфери особистого в політичний простір, що дозволило заново поставити питання людської суб' єктності та ідентичності.

Погоджуючись із періодизацією, запропонованою С. Холлом можна виділити три найбільш загальні теоретичні моделі наукового розуміння суб'єктності, доповнюючи їх важливими теоретичними наробками, що послугували теоретичній та практичній розробці суб'єкту постструктуралістської теорії дискурсу [18]: суб'єкт епохи Просвітництва; соиіологічний суб'єкт; постмодерністський суб' єкт.

Суб’єкт епохи Просвітництва бере відлік із явища, що визначається М. Фуко як «картезіанський момент». Воно полягає у тому, що доступ до істини стає можливим при наявності лише самого акту пізнання суб'єкта, який почав вважатися єдиною необхідною субстанцією для розпізнання істини всередині самого себе, ставши єдиною умовою будь-якого наукового аналізу [14]. Що це означало для розуміння моделі суб'єкту? Приблизно наступне: суб'єкт, будучи умовою, мірою та межею

(C) Котов Е. В., 2018 
істинності стає основоположним моментом в будь-яких теоретичних конструктах, вищою, самототожною та абсолютною цінністю. Його ідентичність приймає форму незалежного стану. Для епохи Просвітництва людина є структура, котра у найсміливіших форма може буту набута через «переродження», проте в цілому $\epsilon$ іманентною тї сутності. Відбувається становлення та затвердження денотативної наукової метамови в моделі знання с презумпцією суб'єкта, в котрій результати теоретичних та емпіричних побудов, безумовно, можуть бути помилковими у результуючих конструктах, проте не в своїх апріорно-прескрептивних засадах.

3 розвитком наукової метамови - "кантіанським поворотом" в філософії, становленням позитивістського інструментарію і затвердженням соціології, - відбувається перехід від сталої, класичної концепції суб'єкта, який тепер трактується в ключі детермінаційних категорій соціуму. Тобто, соціологічний суб'єкт - це суб'єкт, породжений позитивізмом, суб'єкт, що сприймається, аналізується та класифікується за ступенем взаємодії і в категоріях становлення (соціалізації) всередині соціуму. Наприклад, на думку Ч. Кулі, індивід є невіддільною частиною суспільного організму, яка розвивається за його подобою, набуває всі свої риси лише в зіткненні з різного роду громадськими структурами, за допомогою "соціального і біологічного успадкування" [8]. При цьому суб'єкт не скасовується в якості виробника соціальних значень. Це не єдиновекторно задана взаємодія, де людина займає позицію об'єкта гри соціальних значень (втім, таке визначення $€$ анахронізмом). Органічний підхід робить акцент на значущості як суспільства для становлення індивіда, так і навпаки, індивідуального і унікального вкладу кожного окремого суб'єкта в розвиток і функціонування громадських структур.

Втім, суб'єкт продовжує зберігати есенціалістсько-іманентну сутність, яка ніби скульптура проходить огранювання громадськими структурами. Безумовно, дана соціологічна доктрина не $\epsilon$ єдино-представленою в науковій думці розглянутого відрізка часу. Даний перехід від наукового гуманізму до презумпції соціального повною мірою відображений, наприклад, в марксизмі. Де людиноцентризм раннього Маркса, в якому людина представлена як форма чистої і невід’ємною свободи (що складає сутність суб'єкта) і є обгрунтуванням будь-якого політичного утворення, кінцевою телеологією якого є втілення цієї людської сутності. Приходить друга форма в розумінні суб'єкта характерна для сформованої і більш популярною форми марксизму. У "Німецькій ідеології" К. Маркс і Ф. Енгельс дійшли висновку, що людська свідомість є похідною формою матеріальних умов буття: "Не свідомість визначає життя, а життя визначає свідомість" [11, с. 25]

Свідомість завжди є продукт соціальних відносин індивідів. 3 чого випливає, що абсолютно відчужений індивід (не тільки від засобів виробництва, а й від сформованих соціальних відносин) не має якої б то не було об'єктивної форми свідомості, а тому не може вважатися суб'єктом.

Такий тип формування свідомості, а, отже, і суб' єктності ілюструється прикладом ставлення до природи, i, отже один до одного в первісних суспільствах. Страх перед природними силами є стадія прото-суспільної свідомості, що $\epsilon$ формою наділення природи божественними атрибутами («німецька ідеологія»), іiі існування можливе лише остільки, оскільки хід історії ще не дозволив діяльним індивідам трансформувати умови матеріального буття. Першим же кроком до встановлення іншого типу відносин (а тому і перехід до нової форми свідомості і суб'єктності) $€$ первинна форма свідомості - усвідомлення необхідності спільної діяльності, тобто об'єднання в досить стихійну, але необхідну форму спільноти.

Далі, важливо відзначити, що Маркс і Енгельс вказують на той факт, що справжній поділ праці, що веде до нових форм помилкового трактування концепту людської свідомості, відбувається з того моменту, коли диференціюється фізична (матеріальна) і духовна праця. Це негативно позначається на понятті суб'єкта, тому що цей період пов'язаний 3 виникненням концепту свідомості, i допущенням його домінування над матеріальним світом, що призводить до висновків про неповторність і відособленость індивідуального над суспільним [11].

Таким чином, в класичному (пізньому) марксизмі акцент зміщується 3 конкретного, особистісного суб'єкта на суб'єкт надіндівідуальний, колективний, який підпорядкований матеріальним умовам. Суб'єкт розглядається не в формі вихідної трансцендентної сутності свободи, як в рамках раннього марксизму, або в світлі інстанції, яка володіє певним набором ментальних (метафізичних) характеристик. Він (суб'єкт) сприймається не інакше як чистий аркуш, неотесаний камінь, який проходить огранювання за допомогою впливу матеріальних умов (виражених в економічних і соціальних відносинах). Він являє собою не більше, ніж розвинений тип фізичних потенцій, що дозволяють йому встановити деякого роду взаємодію з умовами власного існування, по мірі розвитку удосконалюючи їх, а через них, й власну свідомість. 
Іншою важливою віхою в розвитку розуміння суб'єктності, що, крім іншого, счинила вплив на дискурсивну методологію став психоаналіз. Головним внеском психоаналітичної традиції стала апеляція до «несвідомого». Безумовно виділення пласта несвідомого як конституюючого вектору суб'єктності не є лише психоаналітичною інновацією, а має глибоке коріння, яке, при результуючому висновку можливо доповнити масштабною історіографічною базою, починаючи 3 праць найдавніших філософів. Втім, ми не ставимо собі за мету розгляд історіографії концепту несвідомого та / або історії психоаналітичної традиції. Звернення до психоаналізу обумовлено в першу чергу тим, що саме даній теоретичній парадигмі даний концепт зобов'язаний своєю широкою науковою (гуманітарної) популяризацією i вживанням. Крім того, той факт, що психоаналітична традиція вкрай складна і різновекторна - не підлягає сумніву. Тому, відразу обмовимося щодо того, що, як і в раніше поданій історико-наукової ретроспективі, ми маємо на увазі певний узагальнений (можливо навіть спрощений) теоретичний конструкт даної традиції, 3 метою виділення ключових елементів, які вплинули на становлення і розвиток тієї моделі суб’єктності, яка представлена в роботі (а саме, постструктуралістскій концепції суб'єкта).

Отже, на першому етапі свого становлення психоаналітична традиція представляє в деякому роді відмінне від домінуючого в цей час трактування "суб'єктності". 3. Фрейд пропонує розділити (пласт того, що раніше вважалося в якості свідомості) на три частини: "Воно" "Я" "Над Я" [9].

Воно виступає величезним пластом несвідомого.

Я - тим, що ототожнюється (в даний історико-науковий період) із свідомістю (насправді є результатом внутрішніх інтерпсихічних бажань і потреб "Воно", відфільтрованих (i тому сублімованих) за допомогою конструкту "Над Я");

Над Я - інтеріоризованний пласт культурних кліше, патернів і табу.

Отже, оминаючи ряд уточнень, можна сказати, що несвідоме в психоаналітичній традиції представлено відразу в декількох формах (приховане / латентне несвідоме, витіснене несвідоме; "Над Я", тобто, соціальне несвідоме), крім того, вагоме місце займає концепція передсвідомого, що $\epsilon$ опосередкованою ланкою / елементом між свідомістю і несвідомим. Виходячи з цього, необхідно позначити подвійну природу несвідомого, що має, з одного боку, трансцендентальні підстави, виражені в ( "низинних") в т. ч., але не виключно сексуальних бажаннях, комплексах, представлених в психіці кожного індивіда, а з іншого боку, воно $є$ суть ряд партикулярних психічних процесів, що формулюють окремі частини несвідомого (передумовою такого розуміння служить той факт, що мова дешифрування символів несвідомого завжди являє собою суміш універсальних формул $\mathrm{i}$ контекстуальних асоціативних методик) [9].

Втім, несвідоме формулюється не на доступній для кожного мові, воно має свою "логіку", а тому представлено у вигляді символів, метафор, обмовлень і лише той, хто має "ключ" для дешифрування цієї символічної мови зможе частково стикнутися з таємницею / чорним ящиком несвідомого.

Далі психоаналітична традиція трансформується в аналітичну психологію, в рамках якої функція лібідо, що лежить в основі несвідомого істотно трансформується в концепт колективного несвідомого, що є продуктом еволюції людського розуму, представленого у вигляді архетипів базових елементів культури, схематичних і символічних, розгортаємих та доповнюваних партикулярними культурними елементами [6].

Крім того, важливо відзначити, що психоаналітична теорія, наслідуючи в деякій мірі класичний трансценденталізм констатує поділ двох типів реальності: матеріальної і психічної (тобто даної в свідомості суб'єкта). Суб'єкт в рамках традиції стає подвійним, розщепленим між свідомістю і несвідомим, які більше не являють узагальнений концепт на виході.

Вище нами була дана досить оглядова скорочена і ні в якій мірі не вичерпна характеристика наукових підстав в розумінні суб'єктності в попередні історико-наукові епохи, метою якої було окреслити основні моменти домінуючого розуміння суб'єкта в науковому середовищі. Третій «етап» теоретичного розвитку концепту суб'єкта, пов'язаний із постмодерністською течією і визначається насамперед в рамках ідеї «смерті суб'єкта», яка у найзагальніших рисах виражена у відході від концепту "людина", імпліцитно стверджуючого наявність деякого "Я", незалежно від того яким чином воно конституйовано.

Таким чином, постмодерністський підхід також можна визначити в категоріях метафізики звільнення, усунення поліваріантних кайданів людської, соціальної або якої б то не було іншої форми екзистенції. Зазначені "завдання", виконуються за допомогою нівелювання і деперсоніфікації дій, які стали результатом текстуальної деконструкції онтології. Позатекстова реальність, 
т. ч., перестає існувати не в тому сенсі, що стає не цікавою або другорядною для будь-якого суб'єкта, що пізнає, а в тому, що вона не може бути дана безпосередньо, у відриві від мови, через яку їі репрезентовано [4].

У зв'язку з цим виникає ряд закономірних питань, одне з найбільш поширених звучить так: "Чи не $\epsilon$ такий підхід розвиненою ідеалістичною парадигмою, що заперечує буття субстрату поза його репрезентацією в мові?". Звинувачення в ідеалістичному характері постмодерністського наукового знання стало вже практично класичним (як би це не було парадоксально по відношенню до постмодерну).

Відповідь на нього можна сформулювати, посилаючись на теоретиків дискурс-аналітичного підходу, які в роботі "Постмарксизм без вибачень" [19] вказують, що: ставлення до будь-якого типу об'єкту (зокрема наводячи в приклад «камінь» або «молоток») як до естетичного предмету мистецтва або як снаряду праці, або ж знаряддя для фізичного зіткнення - результат взаємодії індивіда $з$ цим об'єктом, а, отже, це відношення залежить від тих чи інших форм «дискурсивної артикуляції», при цьому саме існування даного об'єкта в реальності є безсумнівним, акцент робиться на тому, що будь-який об'єкт стає значущим лише у взаємодії із суб'єктом, доступ і сприйняття якого обумовлені різного типу дискурсивними формаціями. Т. ч., подібного роду твердження / звинувачення виходять з плутанини в поняттях існування (як об'єкта матеріального світу) і сутністю (феноменом), що являють "справжню" природу об'єкта. Більш того, тут важливо відзначити, що дискурсивність не є лише форма тексту, дискурсивність набагато складніший і багатошаровий феномен, що включає в себе і всі соціальні явища, тобто все, що так чи інакше має значення в семантичному просторі [19].

Отже, повертаючись до розглядаємого питання, необхідно зазначити, що постмодерністські інтенції в розумінні суб'єкта, так чи інакше пов'язані з ім'ям Л. Альтюссера, що хоч і не належить до даної філософської доктрини, проте, саме його «антигуманістичну» концепція дозволяє виявити різницю між матеріальними умовами буття, структурованими (в деякій мірі) доктринами, опосередковуючими доступ до дійсності і свідомостю (яка виступає в свою чергу як "специфічна форма несвідомого" [1]. При цьому, домінантними виступають перша і друга сутності, формулюючи свідомість як повністю підконтрольну їм.

Отже, звертаючись до категорії "структурних утворень" необхідно зазначити, що відповідно до Л. Альтюсера, в основі опосередкованості емпіричного досвіду індивіда лежить суворо організована, частково формалізована структура під якою ним мається на увазі "ідеологія", противагою якій Л. Альтюсер вважає науковий тип свідомості [1]. Увага при цьому сконцентрована на тому, що ідеологічна форма свідомості, на відміну від наукової: по-перше, не в змозі надати повний спектр аналітичних концептів, призначених для неупередженої категоризації та класифікації, отримуваних даних із метою досягнення "чистого пізнання", даючи можливість визначення лише вектору в спробі неаангажованої репрезентації всієї сукупності соціального; подруге, в рамках ідеології наявне превалювання практичної (такої, що А. Грамші визначав як "буденну") над теоретичною (науковою) свідомістю. Виходячи з цього, ідеологію потрібно розуміти як необхідну основу для життєдіяльності суспільства.

Л. Альтюсер здійснив значний внесок у розвиток дискурс-аналітичної теорії, трансформуючи розуміння суб'єктивності, вводячи необхідну компоненту у взаємодії людини і матеріального світу, зміщуючи тим самим вектор розгляду з індивіда до тих підстав, що цього індивіда допускають. Тобто, перефразовуючи М. Фуко, поняття "ідеологічних структур", висунуте вченим: "... стає епістемологічним індикатором, що вказувало на проблеми, які вимагали вирішення ... області вивчення, які науці тільки належало відкрити".

Більше того, як вже зазначалося вище - відбувається трансформація самого розуміння людини, яка тепер не виступає основою будь-якої теоретичної побудови. Елімінується статус суб'єкта як незалежної ланки, що організовує розглянутий лад дійсності. Вона, таким чином, стає частиною об'єкта, на який, в бінарній концепції з презумпцією суб'єкта, спрямована його перетворююча, пізнавальна або будь-яка інша діяльність. Це означає, що він (суб'єкт) постає в якості структурної лакуни як підпорядкованої, так і володіючої владою по відношенню (поки ще) до ідеології.

Окрім того, важливо визначити науковців, які попри частковий і супутній розгляд даного питання, зробили, тим не менш, вагомий внесок в його розвиток. До таких можна віднести, наприклад, Ж. Ф. Ліотар, який, в свою чергу, констатує небачений рівень еклектичності постсучасного соціального, культурного, політичного просторів. Розмиття стандартизованих поведінкових і ментальних стереотипів і патернів. Їх трансформацію в напрямку синтезу 
не синтезованного [9]. Ю. Крістєву, що акцентує увагу на тому, що суб'єкт не може бути повністю виключеним зі сфери теоретичного аналізу, вказуючи, що однією з основних (нехай і не єдиною) функцією мови є передача інформації від одного суб'єкта іншому, тому пропонує говорити про "процесуальний суб'єкт мови [7].

Для Р. Барта, суб'єкт є певна позиція всередині мовленнєвого акту, яка не має іншого буття. Під цим мається на увазі неможливість розуміння суб'єкта як такого, що має деяку трансцендентну сутність, через те, що будь-який атрибут даної суті є нічим іншим, як певним словником, складеним без його участі і відсилаючим до нескінченного багатоманіття інших словників, цитат і значень. Отже, безглуздо говорити як про унікальність суб'єкта, так і про наявність інтерсуб'ектних характеристик існування, що передують будь-якої моделі безпосереднього діяча [2]. Такий підхід породжує нескінченність семантичних значень щодо будь-якого явища або процесу, приводячи до абсолютного плюралізму наукових доктрин, які не мають об'єктивних підстав для визначення власних результатів в якості істинних. Т. ч., науковець (або читач в роботах Р. Барта), організує емпіричний матеріал відповідно до деяких наукових уявлень, що знаходяться в основі даного спостереження, і вести мову про дані, що збираються подібним чином, релевантно виключно в рамках даного парадигмального підходу. Сам процес думки, в такому випадку не більше, ніж оперування сформованим словником і спроба його екстраполяції, що являє собою нескінченну зміну і доповнення одних термінологічних апаратів іншими [2].

Найбільш важливо, як нам здається, зупиниться детальніше на ідеях французького мислителя М. Фуко, тому що складно уявити вченого, який би зробив більший внесок у розвиток не тільки поняття суб'єктності, але і всього напряму дискурсивної методології. Його заслугою є те, що ним самим було визначено як відкриття нового простору думки, i, навіть більше того, він вказав яким чином і в якому напрямку в цьому просторі необхідно просуватися.

Отже, для М. Фуко людина є істота мисляча, але спосіб і форми його мислення завжди опосередковані відносинами влади, які в свою чергу, є структуруючим механізмом, природа якого полягає не в примусі або згоді, що представляють інструменти, але не логос влади, а в невідворотності впливу одних людей на інших. Фуко вважає, що вся попередня історіографія влади самоскомпрометована щодо пояснення цього феномену. Оскільки, усі здійснені спроби об'єктивації влади припускали істотне редуціювання даного концепту до його форм, як то влада політична, економічна і т. д., крім того, вони (дослідники) помилково визначали владу через механізми примусу та / або згоди то протиставляючи, то синтезуючи їх. У той час, як для М. Фуко примус і згода $\epsilon$ тим, без чого неможливо уявити будь-яку владу, але разом з тим, вони $\epsilon$ не більше ніж інструментами, що ніяким чином не співвідносяться із владною природою, що лежить, як уже було сказано, в полі незворотності взаємодії, а тому і впливу однієї людини на іншу, але такий тип впливу не обмежено виключно в комунікації або об'єктивній можливості (до прикл. фізичного перетворення будь-яких предметів).

Тому, для М. Фуко важливо досліджувати механізми та інститути, які відтворюють владні відносини на імпліцитному рівні (в різного роду соціальних інституціях, таких як в'язниці [16], психіатричних і освітніх установах [16].

При цьому, важливим моментом в дослідженнях, об'єктивуючих владне відтворення в соціальних інститутах будь-якого типу, є дослідження цього впливу не 3 точки зору самих інститутів, т. щ. таке дослідження завжди пов'язане з надмірним ризиком виявлення в самому об'єкті вихідного пояснення поняття, витоків і механізмів влади, що призводить до визначення влади через саму владу [15].

Для того, щоб зрозуміти яким чином питання влади співвідноситься 3 трансформацією суб'єктності необхідно визначити основні моменти щодо нього [16]:

- по-перше, щоб уникнути вузьконаправленого трактування концепції влади, М. Фуко акцентує увагу на тому, що владу неможливо набути або завоювати, вона не є щось, що саме виступає предметом боротьби, вона черпає себе (самовідтворюється) через безліч точок, відносини між якими можуть коливатися від антагоністичних до агоністичних;

- по-друге, відносини влади не $\epsilon$ когерентною зовнішньою стороною різних відносин інших типів, тому їх неможливо відокремити від соціального тіла, зробивши винятковим предметом розгляду, вони, в свою чергу, іманентні будь-якому іншому типу відносин, відтворюючи диференціації та відмінності;

- по-трете, "влада виходить знизу", що означає неможливість класичного протиставлення на тих, хто наділений владою і підлеглих ( "пана" і "раба" в поділі Гегеля, наприкл.) з презумпцією 
перших. Оскільки, "нижчі" точки соціального в розподілі владних ефектів є основою сукупної моделі (системи, яка ніколи не буває єдиною і суворо визначеною), що впливає надалі на усю безліч соціальних мікроцентрів ( "мікро" при цьому, як уже було сказано, не має на увазі наявність "макро" центру) відтворюючи "гегемонічний ефект влади";

- по-четверте, "відносини влади є одночасно й інтенціональними й несуб'єктними" [16, с. 130], Що означає відсутність єдиного центру прийняття рішень або певної точки, що організує структуру, тому що наявність такого центру, згідно Ж. Дерріда [5] необхідно передбачає його трансцендентальний характер, а, крім того, такий центр, структуруючи структуру сам повинен знаходитися поза будь-якою формою структурування. Відносини влади - суть, відносини різних точок сили. Отже, те, що визначено як інтенціональність є типи рішень, обумовлених владними диспозитивами, що може привести до висновку про те, що такого типу рішення є вторинною структурою, але це не зовсім так. Важливо відзначити, що подібні "рішення" (політичні, наприкл.) схожі 3 типом відношень між суб'єктом і дискурсом, це означає, що будь-яке рішення, хоч i безумовно детерміновано різного ступеня седиментованими структурами не може бути зрозуміле виключно в термінах традиції, воно, будучи чимось, що спирається на превалюючу епістему завжди до деякої міри трансформує іiі;

- i, по-п’яте, відносини влади 3 необхідністю припускають інституцію, що протистоїть або знаходиться 3 ними у відносинах, які визначаються як антагоністичні, але, згідно з М. Фуко, апелюючого до того ж аргументу, що і П. Бурдьє та Ж. Бодріяр [3], протиставлена субстанція вже включена в те, чому вона протистоїть, будучи їі невід’ємною ознакою і доповненням, в силу того, що протиборча сторона, т. ч., приймає існування якогось концепту того, що намагається виключити на владному рівні як данність. Тому влада не має антагоніста, вона суть і є власний антипод.

Отже, означивши деякі аргументи 3 теорії влади М. Фуко, необхідно визначити як це співвідноситься з розглянутою проблемою трансформації поняття суб'єкта. В рамках теорії М. Фуко суб'єкт завжди сврехдетермінований структурами мови, відносинами влади і диспозитивами знання (тобто, існуючими епістемологічними рамками, встановленими владними відносинами), що фактично є дефініцією концепту "дискурс". Отже, суб’єкт є непостійна, вироблена дискурсом ідентичність, що завжди вислизає з простору (поля) аналізу. Тому, виходячи з еволюції наукового концепту суб'єкта необхідно констатувати, що єдино можлива форма його розгляду укладена в аналізі дискурсивних підстав (можливостей) його допускаючих. Тому, на нашу думку, кажучи про "смерть суб'єкта", насправді говорять про відмову від існуючої модерністської моделі наукової суб'єктної центрованності і зміщення вектора аналізу на самі умови.

Таким чином, власне процес змін в розумінні суб'єктності прийнято називати "деконструкцією суб'єкта", відсилаючи нас до концептів Ж. Дерріди, що відкидає ідею наявності ессенціальноіманентної (феноменальної) сутності (природи) об'єктів. Даний теоретико-методологічний інструмент заснований на перегляді ідеї про те, що для будь-якого об'єкта можна виділити певний набір якостей, що визначають його природу, незалежно від ступеню і характеру їх імпліцитності. Що призводить до того, що вся сформована структура пізнаваного об'єкта (втім, як і суб'єкта) являє собою не феномен (висловлюючись в категоріях феноменології), а лише логоцентричну модель, яка $\epsilon$ ніщо інше як одна з нескінченної кількості (потенційних можливостей / форм).

Отже, елімінація суб'єкта покликана змінити його статус в метанарративі науки, в рамках якої суб'єкт виступає результатом суб'екціі, тобто дії необхідної для визначення його як предмету наукового аналізу. Де його характеристикою $\epsilon$, серед іншого, усвідомленість і визначеність соціальної ролі, яка в контексті вакації суб'єкта приймає форму однієї з численних форм самоідентифікації. Це призводить до того, що в сучасних політичних процесах дії індивіда деперсоніфіціруются, будучи результатом детермінованості суб'єкта всередині дискурсивного поля, що надає йому можливі, але обмежені превалюючим (гегемонним) дискурсом шляхи суб'єктивації. Так, окремо взятий індивід, що покладається у своїй діяльності на ряд стійких ментальних диспозицій, в дійсності, існує у вигляді фрагментарної ідентичності, обумовленої дискурсами.

\section{Бібліографічний список:}

1. Альтюссер Л. За Маркса. / Пер. с франц. А. Денежкина. - М.: Праксис. - 2006.

2. Барт Р. Избранные работы: Семиотика: Поэтика / Пер. с франц. Г. Косикова. - М.: Прогресс, 1989. $616 \mathrm{c}$.

3. Бодрийар Ж. Симулякры и симуляция. / Пер. с франц. А. Качалова. - М.: Рипол-классик. 2011. - 250 с.

4. Деррида Ж. О Грамматологии / Пер. с франц. Н. Автономовой. - M.: «Ad Marginem», 2000. - 508 с. 
5. Деррида Ж. Письмо и различие. / Пер. с франц. Д. Кралечкина под ред. В. Кузнецова. - М.: Академический Проект, 2000. - 495 с.

6. Карл Г. Ю. Архетип и символ / Пер. с нем. В. Зеленского. - М.: Ренессанс, -1992.

7. Кристева Ю. От одной идентичности к другой [Електронний ресурс] / Ю. Кристева // Режим доступу: https://www.gumer.info/bogoslov_Buks/Philos/krist/otodn.php

8. Кули Ч. Человеческая природа и социальный порядок [Електронний ресурс] / Ч. Кули // Режим доступу: https://www.libfox.ru/370592-charlz-kuli-chelovecheskaya-priroda-i-sotsialnyy-poryadok.html

9. Лейбин В. Психоанализ: Учебное пособие. 2-е изд. - СПб.: Питер, 2008. - 592 с.

10. Лиотар Ж. Ф. Постмодерн в изложении для детей. Письма 1982-1985. / Пер. с франц. А. Гараджи. М.: Рос. гос. гуманит. ун-т. 2008. - 145 с.

11. Маркс К., Энгельс Ф. Немецкая идеология Т. 3. / М.: Гос. изд. полит. лит-ры. 1955. - 630 с.

12. Фрейд 3. Толкование сновидений. / Пер. с нем. А. Боковикова. - М.: Академический Проект, 2007. $512 \mathrm{c}$.

13. Фуко М. Археология знания. / Пер. с фр. М. Б. Раковой, А. Ю. Серебрянниковой. - СПб: Гуманитарная Академия, 2004. - 416 с.

14. Фуко М. Герменевтика субъекта: курс лекций, прочитанных в Колеж Де Франс в 1981-1982 учебном году. / Пер. с франц. А. Погоняйло. - СПб: «Наука». 2007. - 677 с.

15. Фуко М. Интеллектуалы и власть. / Пер. с франц. Б. М. Скуратова под общей ред. В. П. Большакова. М.: Праксис, 2006. ч. 3. -320 с.

16. Фуко М. История сексуальности. / Пер. с франц. - М.: Касталь, 1996. - 448 с.

17. Фуко М. Надзирать и наказывать. Рождение тюрьмы. / Пер. с франц. В.Наумова под ред. И. Борисовой. - M.: «Ad Marginem». - 1999.

18. Hall S., Held D., Hubert D., Thompson K. Modernity an Introduction to Modern Societies / MA.: Blackwell. 1996. $-672 \mathrm{p}$.

19. Laclau E., Mouffe C. Post-Marxism Without Apologies [Електронний pecypc] / C. Mouffe, E. Laclau // Режим доступу: https://libcom.org/library/post-marxism-without-apologies

Kotov E. V. Theoretical principles of the use of discourse analysis for research of a political subject

The theoretical evolution of the scientific concept "subject" has been analyzed through the prism of various historical and philosophical epochs and scientific doctrines in the article. The paradigmatic periodization of the development of the mentioned concept with the theoretical additions of those scientific schools, which influenced the post-modern understanding of the subject as part of socio-political knowledge, was given. The author presents the main theoretical articles on understanding the concept of subjectivity as part of the following theoretical and practical doctrines: the sociological approach (represented by the analysis of the works of Ch. Cooley); early and classic Marxism (between which differentiation is under consideration on the subject under the vector humanism / sociologism (antihumanism) ) including the French neo-Marxist school presented by the works of L. Althusser; psychoanalysis, which allowed to determine the importance of the unconscious as the constitutive vector of subjectivity; analytical psychology emphasizes the archetypal composition of the unconscious; postmodernism (represented by the works of J. Derrida, JF Lyotard, J. Kristeva, R. Barthes), which raises the question of the textual deconstruction of ontology and any form of logocentrism; in addition, the concept of " power " in the works of M. Foucault in connection with the transformation of the understanding of subjectivity and discourse was analyzed. On the basis of the above, the author tries to prove that the modern type of understanding of the subject takes its countdown from the philosophy of the Enlightenment, while understanding the exhaustiveness of the explanatory potential of the existing model, the author points to the historical and cultural conditionality of any episteme, assuming that at this stage scientific knowledge it is necessary to talk about an analysis of the subject as part of discursive methodology, which will open the new ways in understanding of post-time political processes.

Key words: subject, discourse, postmodernism, post-structuralism, "death of the subject". 